\title{
Model Respon Emergensi Bencana Dan Pengaruhnya Terhadap Kinerja Akuntan Pendidik Dalam Pandemi Covid-19 Di Provinsi Sumatera Utara
}

\author{
Azizul Kholis ${ }^{1}$, Dedy Husrizalsyah ${ }^{2}$, Rini Indah Wati ${ }^{3}$ \\ Universitas Negeri Medan ${ }^{1,2}$, Politeknik Negeri Medan ${ }^{3}$ \\ azizulkholis@unimed.ac.id ${ }^{1}$, dedy@unimed.in²,riniindahwati@polmed.ac.id ${ }^{3}$
}

\begin{abstract}
Abstrak: Penelitan ini bertujuan untuk mendapatkan suatu Model sikap Emergensi dan Respon cepat kesiapsiagaan terhadap terjadinya suatu bencana, khususnya pandemi virus corona (Covid-19) yang terjadi saat ini dan pengaruhnya terhadap kinerja Akuntan Pendidik di Indonesia. Berdasarkan pada Teori kontijensi dengan pengembangan model Respon Emergensi Akuntan pendidik dan Teori Stakeholder untuk melihat faktor eksternal pencapaian kinerja Akuntan pendidik. Populasi penelitian ini adalah Dosen akuntansi di seluruh Provinsi Sumatera Utara, dengan menggunakan teknik sampel kemudahan didapatkan 103 responden. Teknik pengumpulan data dilakukan secara dalam jaringan (daring) dengan membuat kuesioner berbasis online menggunakan Google form dan disebarkan kepada grup WA Forum Dosen Akuntansi Perguruan Tinggi dari berbagai Perguruan Tinggi negeri dan Swasta yang ada di Provinsi Sumatera Utara. Teknik analisis yang digunakan adalah Analisis Regresi berganda dengan tiga model estimasi dan perhitungan data menggunakan Aplikasi Wrapp Partial Least Square (PLS). Hasil penelitian menunjukkan bahwa Pemahaman terhadap Bencana, Memiliki pengaruh terhadap Respon Emergensi, Sedangkan Pengalaman bencana dan Pengetahuan regulasi Kebencanaan tidak berpengaruh. Temuan lainnya semua variabel berpengaruh positif signifikan terhdap Kinerja Akuntan Pendidik. Hasil penelitian ini ini dapat menjadi suatu Model Emergensi yang adaptif. Keterbatasan penelitian ini adalah pada sampel yang hanya Akuntan Pendidik dan diwilayah Sumatera Utara saja, saran untuk penelitian berikutnya adalah dapat diteliti pada lintas profesi akuntan lainnya, khususnya akuntan manajemen karena berdampak langsung pada dunia usaha dan pada wilayah yang lebih luas. Implikasi Penelitian adalah pentingnya pengaturan regulasi dan SOP bagi IAI KAPD dan organisasi IAI terkait kebencanaan secara internal.
\end{abstract}

Kata Kunci : Respon, Emergensi, Akuntan Pendidik, Covid-19 


\section{Model Respon Emergensi Bencana Dan Pengaruhnya \\ Terhadap Kinerja Akuntan Pendidik Dalam Pandemi \\ Covid-19 Di Provinsi Sumatera Utara}

\section{Pendahuluan}

Sejak World Health Organizattion (WHO) menetapkan COVID-19 sebagai pandemi pada 11 Maret 2020, seluruh negara termasuk Indonesia telah menerapkan berbagai upaya pencegahan. Kebijakan yang diambil adalah menetapkan Pembatasan Sosial Berskala Besar (PSBB), sebagai kebijakan untuk membatasi pergerakan orang dan barang. Kebijakan tersebut ditetapkan melalui Peraturan Pemerintah No. 21 tahun 2020 dan pelaksanaannya diatur dalam Peraturan Menteri Kesehatan RI Nomor 9 tahun 2020. Beberapa daerah yang sudah menerapkan PSBB adalah Provinsi DKI Jakarta, Kota Pekanbaru, Kota Surabaya dan beberapa Kabupaten/Kota lainnya di seluruh Indonesia. (Irman, 2020).

Pandemi Covid-19 yang dihadapi bangsa Indonesia merupakan suatu bencana besar yang sedang dihadapi. Menurut Kajian Badan Penanggulangan Bencana Nasional (2012), bahwa banyaknya korban jiwa dan terhambatnya berbagai aktifitas saat terjadi bencana dikarena ketidak fahaman masyarakat dalam merespon bencana tersebut. Penelitian Ayub, dkk (2019) yang dilakukan setelah bencana, menyebutkan bahwa banyaknya korban jiwa pada suatu bencana yang terjadi disebabkan para korban tidak mempunyai pengetahuan tentang bencana dan bagaimana sikap terhadap manajemen bencana yang harus dilakukan dan sikap emergensi yang harus dimiliki oleh masyarakat. Sejalan dengan Ayub (2019) Nurmayani (2018) mendefinisikan sikap emergensi/kesiapsiagaan menjadi lebih luas yaitu "meminimalisir akibat-akibat yang merugikan dari suatu bahaya lewat tindakan-tindakan pencegahan yang efektif, rehabilitasi dan pemulihan untuk memastikan pengaturan serta pengiriman bantuan dan pertolongan setelah terjadi bencana secara tepat waktu dan efektif". Ayub dkk (2019) sendiri sudah meneliti tentang kesiapsiagaan guru-guru sekolah dasar dalam menghadapi suatu bencana dan hasilnya menunjukkan bahwa respon guru sangat baik dalam mengantisipasi bencana.

Menyikapi kebijakan Menteri Pendidikan dan Kebudayaan (Mendikbud) Nadiem Anwar Makarim yang telah menerbitkan Surat Edaran Nomor 4 Tahun 2020 tentang Pelaksanaan Pendidikan Dalam Masa Darurat Corona Virus Disease (Covid-19), dan ditindaklanjuti secara teknis oleh Dirjen Dikti kemendibud RI Nomor:302/E.E2/KR/2020 tanggal 31 Maret 2020 perihal masa belajar penyelenggaraan program pendidikan, maka profesi akuntan pendidik sebagai dosen dan pilar dalam penyelenggaraan di perguruan tinggi harus dapat merespon dan menyikapinya secara bijak. Pada satu sisi akuntan pendidik harus mampu merespon keadaan bencana dan sisi lainnya kinerja professional akuntan pendidik sebagai dosen harus tetap berjalan dalam mengemban misi tridarma perguruan tinggi yaitu pendidikan dan pengajaran, penelitian dan pengabdian kepada masyarakat. Hal ini sangat penting karena dapat menjadi sebuah model ataupun pedoman bagi profesi akuntan pendidik dalam menyikapi suatu bencana yang terjadi. Kejadian diperguruan tinggi atau suatu peristiwa seperti bencana yang mengganggu operasi perguruan tinggi yang semestinya berjalan secara normal dan berpotensi menempatkan mahasiswa, pengunjung, fakultas, staf, atau properti berisiko pasti bias saja terjadi. Peristiwa darurat berskala besar termasuk Covid-19 yang terjadi saat ini dan kedepan tidak terbatas pada bencana alam seperti badai, banjir, ancaman atau pelepasan biologis atau kimia, dan tumpahan minyak atau kimia.

Kegiatan pendidikan tinggi ternyata lebih kompleks permasalahannya jika mengalami suatu keadaan bencana, karena bagaimanapun juga kegiatan tridarma perguruan tinggi harus dapat berjalan walaupun dalam keadaan darurat. Hasil riset yang dilakukan oleh Stephen (2016) menunjukkan beberapa perguruan tinggi didunia telah memiliki standar operasional dan prosedur untuk lingkungan kampus dalam menghadapi situasi darurat dan bencana. Bahkan Philips (2017) telah merinci bahwa SOP untuk staf akademik juga telah dibuat berkenaan dengan terganggunya proses belajar mengajar di perguruan tinggi saat terjadinya suatu bencana sehingga apa yang ditargetkan untuk pencapaian kinerja akademik terus berjalan.

Penelitian tentang kinerja profesional akuntan pendidik telah banyak dilakukan di Indonesia diantaranya Mukmin (2017) melihat kinerja akuntan pendidik berdasarkan kompetensi, dan etika profesi. Sementara itu Enny dan Baningatus (2014) melihat profesionalisme akuntan pendidik berdasarkan kualitas lulusan. Sawitri dan Fauziyah (2017) melihat profesionalisme akuntan pendidik dari perspektif profesionalisme calon akuntan. Kinerja profesional akuntan pendidik menjadi suatu ukuran penting karena sebagai salah satu anggota organisasi profesi, akuntan pendidik harus mampu meningkatkan kinerjanya dalam kondisi apapun. Agustia (2019) mengatakan bahwa akuntan pendidik 


\section{Model Respon Emergensi Bencana Dan Pengaruhnya Terhadap Kinerja Akuntan Pendidik Dalam Pandemi Covid-19 Di Provinsi Sumatera Utara}

harus siap dengan distrupsi yang demikian cepat dan tentunya kesiapan untuk berkinerja harus dibuktikan oleh akuntan pendidik walaupun dalam keadaan covid-19. Untuk itu penelitian ini melihat ada permasalahan yang mengemuka dan penting diteliti yaitu mengenai respons emergensi (kesiapsiagaan) profesi akuntan pendidik dalam menyikapi terjadinya bencana khususnya Covid-19 dan bagaimana sebenarnya capaian kinerja akuntan pendidik dalam masa Pandemi Covid-19 di Indonesia. Secara khusus penelitian dilaksanakan di Provinsi Sumatera Utara dikarenakan daerah ini menjadi provinsi dengan kasus covid-19 terbanyak di pulau Sumatera. Melihat data perkembangan jumlah yang terinfeksi corona di Provinsi Sumatera Utara terus mengalami kenaikan, maka dengan demikian profesi akuntan pendidik yang bertempat tinggal di Sumatera Utara khususnya Kota Medan harus lebih waspada dan responsif menyikapi bencana ini dan diyakini tetap bekerja dan berkinerja sebagai dosen yang profesional. Keseluruhan penelitian terdahulu terkait profesionalisme dan kinerja akuntan pendidik dilaksanakan dalam keadaan normal, sedangkan kondisi saat ini akuntan pendidik harus bekerja dari rumah (Work From Home) dan mahasiswa juga belajar dari rumah (Study From Home) dan masyarakat dihimbau harus tetap dirumah (Stay at Home). Tentunya kondisi ini sangat berbeda dengan kondisi normal dimana asumsi semua aktifitas dapat berjalan. Sedangkan dalam kondisi bencana Covid-19 seperti ini setidaknya dua permasalahan yang harus dihadapi oleh akuntan pendidik yaitu bagaimana menghadapi bencana dan bagaimana dapat mencapai kinerja dalam keadaan bencana tersebut. Untuk itu perlu dilakukan sebuah penelitian tentang kinerja akuntan pendidik dalam keadaan bencana yang kaitannya dengan respon terhadap bencana tersebut. Berdasarakan permasalahan yang dikemukakan tersebut diatas maka rumusan masalah penelitian ini adalah, (1) Apakah pemahaman bencana berpengaruh terhadap respon emergensi, (2) Apakah pengalaman bencana berpengaruh terhadap respon emergensi, (3) Apakah pengetahuan regulasi kebencanaan berpengaruh terhadap respon emergensi, (4) Apakah pemahaman bencana berpengaruh terhadap kinerja akuntan pendidik, (5) Apakah pengalaman bencana berpengaruh terhadap kinerja akuntan pendidik, (6) Apakah pengetahuan regulasi kebencanaan berpengaruh terhadap kinerja akuntan pendidik, (7) Apakah respon emergeni berpengaruh terhadap kinerja akuntan pendidik.

Tujuan penelitian ini untuk mendapatkan model respon emergensi akuntan pendidik berdasarkan pemahaman, pengalaman, dan pengetahuan regulasi terkait kebencanaan dan hubungannya dengan kinerja akuntan pendidik. Sedangkan manfaat penelitian ini secara teoritis adalah untuk berkontribusi terhadap konsep kontinjensi dalam suatu kondisi yang tidak menentu dan konsep stakeholder dalam hal keterkaitan entitas akuntan pendidik dalam situasi apapun sesuai kontinjensi teori dan secara praktis dapat menjadi rujukan kebijakan bagi organisasi IAI khususnya kompatemen akuntan pendidik dalam hal pengaturan internal organisasi pada suatu kondisi jika terjadinya bencana.

\section{Kajian Teori Dan Pengembangan Hipotesis}

Teori Kontinjensi menjelaskan bahwa ketergantungan antar satu variabel dengan kondisi objektif mengakibatkan pengambilan kebijakan dan keputusan harus disesuai dengan kondisi tersebut. Fleksibilitas kontinjensi teori ini diterapkan dalam berbagai bidang termasuk kebencanaan. Menurut Webex, (2020) kontinjensi teori selaras dengan ketepatan tujuan suatu organisasi dan dapat digunakan ketika terjadi perubahan dinamis. Menurut BNPB (2019) ketika bencana terjadi maka semua permasalahan yang muncul harus segera ditangani secara komprehensif. Simon (2020) mengatakan bahwa dampak pandemi Covid-19 sangat erat kaitannya dengan pereknomian dan pasti berdampak pada kinerja bisnis.

Untuk itu seluruh stakeholder yang berkaitan dengan bisnis harus faham dan mampu merespon suatu bencana. Menurut Anderson \& King (2005) respon emergensi dan kesiapan bencana dapat tumbuh berdasarkan pemahaman terhadap bencana, pengalaman bencana dan mitigasi bencana. Penelitian Ayub dkk (2019) menyatakan bahwa tentang kesiapsiagaan dalam menghadapi suatu bencana dan hasilnya menunjukkan bahwa respon yang cepat positif dapat digunakan menjadi sebuah model untuk mengantisipasi bencana. Sutton J., dan Tierney, K. (2006) juga menjelaskan pentingnya pemahaman dan pengalaman bencana sebagai suatu pandangan untuk merespon terjadinya kondisi emergensi. Pendekatan teori lainnya sebagai landasan pengembangan model respon emergensi ini adalah stakeholder theory yang mengatakan untuk menjamin keberlangsungan suatu entitas maka harus melihat faktor-faktor eksternal dari entitas itu sendiri. Jika merujuk pada stakeholder theory 


\section{Model Respon Emergensi Bencana Dan Pengaruhnya Terhadap Kinerja Akuntan Pendidik Dalam Pandemi Covid-19 Di Provinsi Sumatera Utara}

yang dikemukakan oleh Hall (2017) dan Friedman (2007) maka akuntan pendidik harus dapat mengidentifikasi lingkungan eksternalnya pada saat terjadinya bencana. Stakeholder itu sendiri dapat menentukan kesuksesan model emergensi yang terjadi. Lingkungan itu meliputi organisasi profesi, lingkungan kerja, dan masyarakat serta pemerintah. Menurut Marvin dan Delaine (2012) aspek teoritis kebencanaan dan keterkaitan stakeholder meliputi Bencana Kesehatan, Kerangka Konseptual dari Bencana, Kemampuan dan Ketahanan dari Masyarakat yang meliputi Absorbing Capacity dan Buffering Capacity serta Response Capacity, Kerangka Transeksional dan Longitudinal serta peran dari Pelayanan Kesehatan pada masa bencana. Berdasarkan kerangka teoritis dan beberapa hasil penelitian terdahulu yang relevan, maka hipotesis alternatif 1 (satu) yang diajukan penelitian ini dinyatakan :

\section{H1: Pemahaman Bencana berpengaruh terhadap Respon Emergensi}

Menurut Vasilescu et al., (2008), Twigg, (2015), fase penanganan dan response emergensi bencana menjadi penting untuk dipahami dan lebih jelasnya model respon bencana tersebut dapat dilihat pada gambar berikut :

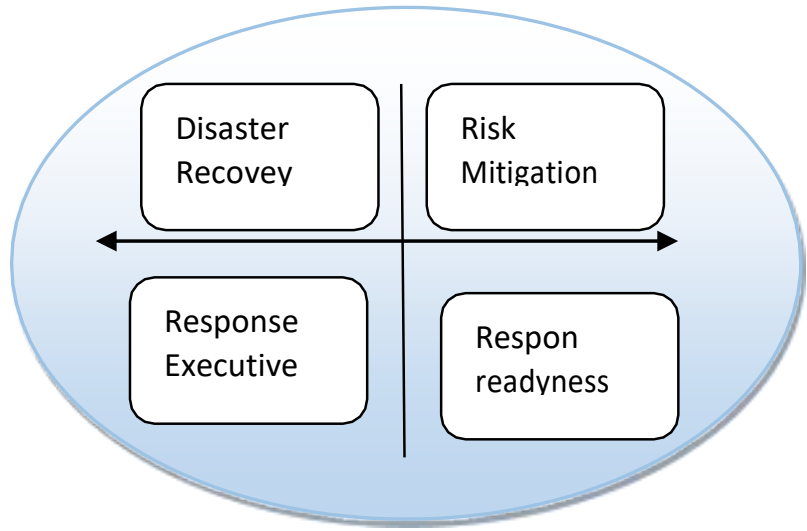

Gambar 1 : Model Respon Emergensi Bencana Sumber: Adaptasi dari Posner and Dransch (2010)

Menurut Posner dan Dransch (2010) : "Main elements of this process are the four 'R's: Risk mitigation(disaster prevention), Response readiness(disaster planning and preparedness), Response execution(disaster relief) and Recovery(disaster recovery). Dengan demikian dapat dipahami bahwa elemen utama dari proses ini adalah empat 'R: mitigasi risiko (pencegahan bencana), kesiapan respons (perencanaan dan kesiapsiagaan bencana), pelaksanaan respons (bantuan bencana) dan pemulihan pemulihan bencana).

Respon emergensi menjadi penting dan faftor kunci untuk menyikapi terjadinya bencana berdasarkan pemahaman, pengalaman, pengetahuan tentang regulasi kebencanaan sehingga temuan temuan penelitian terkait kebencanaan menempatkan respon emergensi menjadi hal yang penting dalam suatu kondisi terjadinya bencana. Anderson \& King (2005) respon emergensi dan kesiapan bencana yang didasarkan pada pemahaman terhadap bencana, pengalaman bencana dan mitigasi bencana akan berpengaruh terhadap situasi dan kondisi kelompok yang menjalani bencana tersebut. Berdsarakan hal tersebut maka Hipotesis 2 (dua) dinyatakan:

\section{H2: Pengalaman Bencana berpengaruh terhadap Respon Emergensi}

Regulasi adalah hal penting yang harus diketahui oleh seseoarang profesional. Berdasarkan UU Akuntan Publik, maka profesi akuntan dituntut untuk memahami dan mengetahui peraturan dan ketentua yang berlaku baik secara internal maupun eksternal profesi. Berdsarakan hasil penelitan Ayub (2010) pemahaman untuk regulasi kebencanaan penting bagi para pendidik karena hal tersebut memiliki pengaruh yang positif terhadap pengendalian bencana yang dihadapi secara individu maupun kelompok pendidik Itu sendiri. Jika dikaitkan dengan teori stakeholder maka penentu suatu entitas memang dipengaruhi oleh banyak pemangku kepentingan baik terlibat secara langsung 


\section{Model Respon Emergensi Bencana Dan Pengaruhnya \\ Terhadap Kinerja Akuntan Pendidik Dalam Pandemi \\ Covid-19 Di Provinsi Sumatera Utara}

ataupun tidak. Berdasrakan hal tersebut maka Hipotesis 3 (tiga) dinyatakan:

H3: Pengetahuan Regulasi terhadap Respon Emergensi

Istilah Kinerja merupakan ukuran dari hasil pekerjaan yang telah dilakukan individu. Untuk mengerti tentang kinerja, individu harus dapat membedakan action dan outcome. Adanya suatu perilaku individu yang berfokus untuk menyelesaikan pekerjaan ialah action. Dan hasil dari suatu pekerjaan yang dilakukan individu disebut dengan outcome. Kedua aspek tersebut adalah bagian utama dari kinerja. Tinggi-rendahnya kinerja individu, harus dilihat dari suatu proses action masingmasing individu (Sonnentag, 2001). Kinerja dipengaruhi oleh 4 hal (Matthew, 2004) yaitu :

1. Information processing : psikologi kognitif menyebutkan betapa information processing theory berpengaruh pada task performance.

2. Stress factor : contohnya seperti bising, panas dan rasa letih.

3. Abilities: Kinerja individu dipengaruhi oleh sesuatu yang telah menjadi kemampuan individu tersebut. Semakin besar tingkat kemampuan yang dimiliki individu, maka kinerja yang ditunjukkan semakin maksimal.

4. Motivation. Setiap individu memiliki semangat dari dalam atau luar diri yang akan mempengaruhi perilaku serta kinerja individu.

Teori McClelland (2004) menjelaskan bahwa kinerja individu dapat diukur atau dilihat dari kegiatan yang dilakukan sehari-hari, contohnya tugas administrasi di kampus. Menurut Jhons (2013), besarnya kontribusi dampak etika profesional, kompetensi akuntan pendidik dapat menjelaskan akuntabilitas kinerja akuntan pendidik, kemudian (2017) menyatakan etika professional dan kompetensi akuntan pendidik dapat menjelaskan akuntabilitas kinerja akuntan pendidik. Menurut Kholis (2012) Kinerja dosen akuntansi setidaknya dilatar belakangi oleh pendidikan, pengalaman dan keahlian dan tentunya sesuai tridarma perguruan tinggi pada kinerja yang dicapai sebagai dosen professional adalah kegiatan yang mencakup pendidikan dan pengajaran, penelitian dan pengabdian kepada masyarakat. Agustia (2019) menekankan bahwa akuntan pendidik harus responsif terhadap lingkunganya dan adaptif terhadap perkembangan situasi dan kondisi yang terjadi diluar lingkungan internal profesinya. Sejalan dengan stakeholder teori yang mengatakan faktor eksternal juga mempengarui kinerja suatu entias sehingga dapat dipahami bahwa pemahaman lingkungan dapat menjadi dasar Kinerja dan memiliki hubungan terhadap kinerja akuntan pendidik. Proses informasi yang mempengaruhi kinerja tersebut diyakini memberikan penguatan pada pemahaman bencana sebagai suatu fakta dan informasi bagi Akuntan Pendidik. Berdasarkan kerangka teoritis dan beberapa hasil penelitian terdahulu yang relevan, maka hipotesis alternatif 4 (empat) dinyatakan:

\section{H4: Pemahaman Bencana berpengaruh terhadap Kinerja Akuntan Pendidik}

Salah satu yang disebutkan oleh Matthew (2004) dalam teori bencana bahwa tingkat stress mempengaruhi kinerja. Jika seseorang sudah pernah mengalami bencana dengan tingkat strestertentu maka diyakini individu tersebut dapat mengendalikan kinerjanya. Pengalaman Bencana secara teori kontinjensi dan stakeholder dapat mempengaruhi kinerja, karena didalam teori Kinerja sendiri diktakan bahwa prestasi atas suatu beban pekerjaan dapat dicapai bilamana individu merasa nyaman dan tidak terganggu dalam melaksanakan pekerjaannya. Kejadian bencana tentulah secara pasti dapat mengganggu rasa aman dan kenyamanan seseorang dalam bekerja. Sehingga individu yang berpengalaman mengatasi bencana dapat mempertahankan kinerjanya. Untuk itu Hipotesis 5 (lima) penelitian ini dinyatakan:

\section{H5: Pengalaman Bencana berpengaruh terhadap Kinerja Akuntan Pendidik}

Regulasi dapat berupa $\mathrm{p}$ [eraturan dan ketentuan yang berlaku dalam sebuah profesi ataupun organisasi profesi. Regulasi diterbitkan oleh Pemerintah ataupun organisasi profesi itu sendiri. Pada organisasi Ikatan Akuntan Indonesia regulasi sudah diatur sedemikian lengkap dan menjadi rujukan utma setiap anggota profesi. Anggota profesi yang baik harus memahami regulasi terkait bidang pekerjaannya baik secara langsung ataupun tidak. Hasil penelitian yagn dilakukan oleh Stphen (2016) membuktikan bahwa Akuntan yang memahami regulasi pada bidang profesinya lebih profesional dibandingkan yang kurang mengetahui regulasi tersebut. Hal ini dapat membuktikan bahwa pengetahuan regulasi sangat penting dan mempengaruhi Kinerja Akuntan, Untuk itu Hipotesis ke 6 


\section{Model Respon Emergensi Bencana Dan Pengaruhnya \\ Terhadap Kinerja Akuntan Pendidik Dalam Pandemi Covid-19 Di Provinsi Sumatera Utara}

(enam) dinyatakan:

\section{H6: Pengetahuan Regulasi terhadap Kinerja Akuntan Pendidik}

Istilah Respon Emergensi memang bukan istilah pada profesi Akuntan, tapi istilah ini adalah pada manajemen kebencanaan. Namun istilah ini sangat penting untuk dipopulerkan pada profesi akuntan mengingat risiko mengalami ataupun menghadapi bencana bisa saja terjadi pada profesi akuntan. Penelitian Ayub (2017) menjelaskan bahwa respon emergensi penting bagi pendidik karena berpengaruh terhadap kesiapan dan pencapaian hasil kerja. Relevansi respon emergensi menjadi bagian utama dalam menghadapi kondisi bencana sehingga semakin baik respon yang dialkukan dapat mengantisipasi keadaan dan memperbaiki kinerja individu yang ingin dicapai. Keempat faktor yang dikemukakan oleh Matthew (2004) jadi penentu bagi individu untuk mempengaruhi Kinerjanya dalam situasi apapun. Interaksi antar variabel tersebut memunculkan respon yang baik terhadap suatu keadaan sehingga dapat mendukung kinerja yang ingin dicapai. Dengan dukungan teoritis tersebut maka, Hipotesis 7 dinyatakan:

\section{H7: Respon Emergensi berpengaruh terhadap Kinerja Akuntan Pendidik}

Keterkatian antar variabel secara teori kontinjensi dan stakeholder yang dihubungkan untuk menggambarkan kerangka konseptual dan pengujian hipotesis penelitian ini adalah:

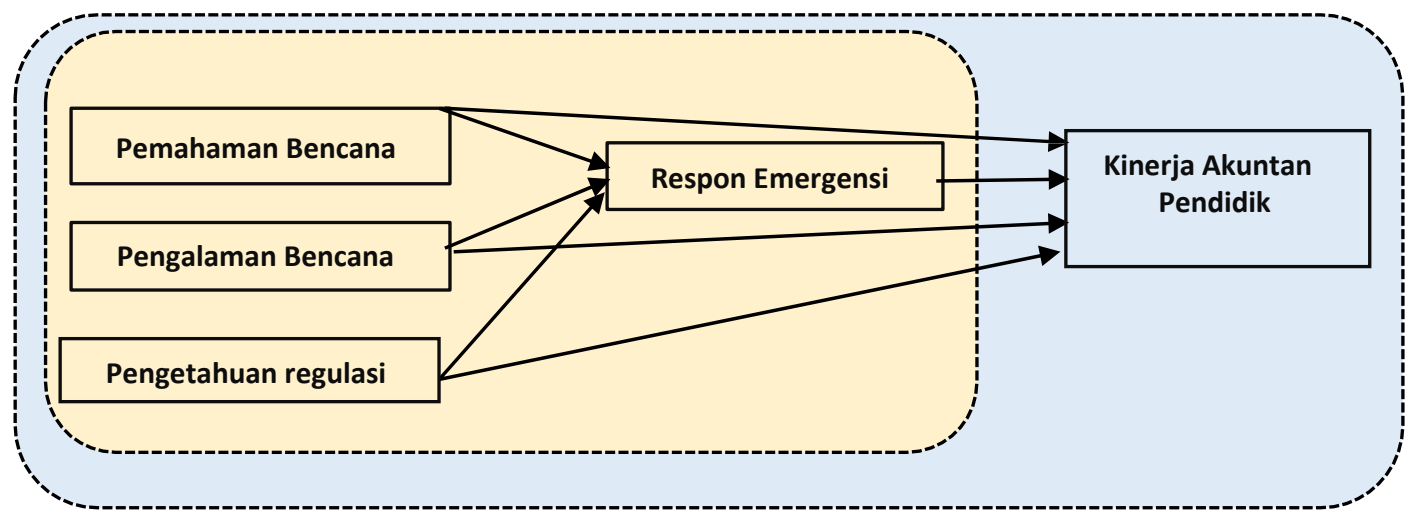

Gambar 2. Kerangka Konseptual

Sumber : Variabel penelitian adaptasi berdasarkan model Posner dan Drasch (2010).

\section{Metode}

Penelitian ini dilaksanakan secara dalam jaringan (daring/online) sejak tanggal 5 Maret s/d 12 April 2020. Populasi penelitan ini adalah seluruh akuntan pendidik/dosen akuntansi yang ada di Provinsi Sumatera Utara yang bekerja pada fakultas ekonomi/bisnis di perguruan tinggi negeri dan perguruan tinggi swasta. Kepastian jumlah populasi (unobserved population) yang tidak tersedia, maka pengambilan sampel dilakukan dengan teknik kemudahan/convinience sampling (Uma, 2005). Pengumpulan data dilakukan dengan menggunakan berbagai aplikasi daring/online dan pemanfataan media sosial yaitu Whatsapp, Facebook, Instagram dan Twitter. Kuesioner penelitian disebarkan dengan menggunakan aplikasi google form yang disebarkan kepada seluruh program studi akuntansi fakultas ekonomi/bisnis mulai level D3, S1, S2 dan S3 pada PTN dan PTS yang ada di provinsi Sumatera Utara dengan mengirimkan ke berbagai grup wa dosen akuntansi, email pribadi, Chat pribadi dan seluruh sosial media yang dimiliki.

Analisis data untuk pengujian hipotesis menggunakan pengujian analisis regresi yang diuji dengan 3 (tiga) model persamaan. Persoalan distribusi normalitas data dan asumsi klasik model dengan kombinasi pengujian bestfit model juga dilakukan untuk memastikan persamaan regresi yang diuji memenuhi ketentuan dan syarat pengujian statistik. Aplikasi 
dalam analisis data yang digunakan adalah aplikasi Wrapp Partial Least Square (PLS). Alasan penggunaan aplikasi ini karena hubungan antar variabel yang saling terkait dapat dilakukan pengujian sekaligus untuk mendapatkan hubungan partial dan simultan keseluruhan variabel dengan jumlah sampel yang relatif kecil. Persamaan regresi dapat dirinci pada Tabel 2 (dua) berikut:

Tabel 2 Model Persamaan Regresi

\begin{tabular}{|c|}
\hline $\begin{array}{c}\text { Model } 1: \mathrm{KAP}=\alpha+\beta \text { PEMB }+\beta \text { PENGB }+\beta \text { PERB }+\varepsilon \\
\text { Model 2: } \mathrm{RE}=\alpha+\beta \mathrm{PEMB}+\beta \mathrm{PENGB}+\beta \mathrm{PERB}+\varepsilon \\
\text { Model } 3: \mathrm{KAP}=\alpha+\beta \mathrm{RE}+\varepsilon\end{array}$ \\
\hline Dimana : \\
\hline$\alpha:$ konstanta \\
\hline$\beta:$ koesfisein Regresi \\
\hline KAP : Kinerja Akuntan Pendidik \\
\hline RE : Respon Emergensi \\
\hline PEMB :Pemahanan Bencana \\
\hline PENB : Pengalaman Bencana \\
\hline PERB : Pengetahuan tentang Regulasi kebencanaan \\
\hline
\end{tabular}

\section{Hasil Dan Pembahasan}

\subsection{Analisis Regresion Linier Berganda}

Jumlah responden penelitian ini yang menjawab kuesioner melalui aplikasi google form adalah sebanyak 103 orang. Adapun demografi reponden dalam penelitian ini dapat dilihat pada rincian tabel 3 (tiga) berikut:

Tabel 3 Demografi Responden

\begin{tabular}{|c|c|c|c|c|c|c|c|c|c|c|c|c|c|c|}
\hline & \multicolumn{2}{|c|}{ Umur (tahun) } & \multicolumn{3}{|c|}{ Jenis kelamin } & \multicolumn{3}{|c|}{ Pendidikan } & \multicolumn{3}{|c|}{ Jabatan Fungsional } & \multicolumn{3}{|c|}{$\begin{array}{c}\text { Masa kerja } \\
\text { (tahun) }\end{array}$} \\
\hline \multicolumn{15}{|c|}{ Angka absolut dan persentase nilai sampel (n) } \\
\hline$<35$ & 12 & 11,65 & \multirow{3}{*}{$\begin{array}{c}\text { Laki- } \\
\text { laki }\end{array}$} & \multirow{3}{*}{63} & \multirow{3}{*}{$\begin{array}{l}61,2 \\
0\end{array}$} & \multirow{3}{*}{$\begin{array}{l}\text { S2/ } \\
\text { Magi } \\
\text { ster }\end{array}$} & \multirow{3}{*}{85} & \multirow{3}{*}{$\begin{array}{l}82,5 \\
0\end{array}$} & $\begin{array}{l}\text { Guru } \\
\text { Besar }\end{array}$ & 1 & 1,00 & $<5$ & 13 & $0^{12,6}$ \\
\hline $\begin{array}{l}36 \text { s.d } \\
45\end{array}$ & 34 & 33,01 & & & & & & & $\begin{array}{l}\text { Lekto } \\
\text { r } \\
\text { kepal } \\
\text { a }\end{array}$ & 16 & 15,50 & $\begin{array}{l}6 \text { s.d } \\
10\end{array}$ & 18 & $0^{17,5}$ \\
\hline $\begin{array}{l}46 \text { s.d } \\
56\end{array}$ & 46 & 44,66 & & & & & & & $\begin{array}{l}\text { Lekto } \\
\mathrm{r}\end{array}$ & 39 & 37,90 & $\begin{array}{l}11 \\
\text { s.d } \\
16\end{array}$ & 30 & $0^{29,1}$ \\
\hline \multirow{2}{*}{$>56$} & \multirow{2}{*}{11} & \multirow{2}{*}{$\begin{array}{l}10,6 \\
8\end{array}$} & \multirow{2}{*}{$\begin{array}{l}\text { Pere } \\
\text { mpu } \\
\text { an }\end{array}$} & \multirow{2}{*}{40} & \multirow{2}{*}{$\begin{array}{l}38,8 \\
0\end{array}$} & \multirow{2}{*}{$\begin{array}{l}\text { S3/ } \\
\text { Dokt } \\
\text { or }\end{array}$} & \multirow{2}{*}{18} & \multirow{2}{*}{$\begin{array}{l}17,5 \\
0\end{array}$} & \multirow{2}{*}{$\begin{array}{l}\text { Asiste } \\
\mathrm{n} \\
\text { Ahli }\end{array}$} & \multirow{2}{*}{47} & \multirow{2}{*}{$\begin{array}{l}45,6 \\
0\end{array}$} & $\begin{array}{l}17 \\
\text { s.d } \\
21 \\
\end{array}$ & 25 & $0^{24,3}$ \\
\hline & & & & & & & & & & & & $>21$ & 17 & $0^{16,5}$ \\
\hline 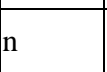 & 103 & $\%^{100}$ & & 103 & $\%$ & & 103 & $\%^{100}$ & & 103 & $\%^{100}$ & & 103 & ${ }_{\%}^{100}$ \\
\hline
\end{tabular}

Sumber : Data penelitian (2020)

Berdasarkan deskripsi demografi responden ditemukan bahwa secara usia/umur para akuntan pendidik lebih banyak berada usia produktif yaitu 44,66 \% dan berjenis kelamin laki-laki yaitu sebanyak $61,20 \%$, namun dari sisi pendidikan nilai tertinggi adalah pada level magister yaitu 82, 50 $\%$ dengan jabatan fungsional tertinggi adalah asisten ahli sebesar 45,60 \% dan secara masa kerja pada nilai 11 s.d 16 tahun sebesar 29,10\%. Data ini menunjukkan bahwa akuntan pendidik di Sumatera Utara masih harus ditingkatkan secara level pendidikan dan kepangkatan akademik karena kedua faktor demografi ini juga diyakini dapat mendorong peningkatan kinerja para akuntan pendidik dalam bidang pendidikan dan pengajaran, penelitian dan pengabdian masyrakat. Krisis utama profesi akuntan pendidik di Sumatera Utara adalah kurangnya guru besar/profesor bidang akuntansi yaitu hanya terdapat 2 (dua) orang saja yang bertugas di FEB Universitas Sumatera Utara, namun guru besar yang menjawab pertanyaan penelitian ini hanya 1(satu) orang. 
Selanjutnya pada tabel 4 (empat) berikut ini menggambarkan tentang pertanyaan penelitian terkait indicator kinerja akuntan pendidik dan lebih jelasnya dapat dilihat sebagai berikut:

Tabel 4. Deskripsi Persentase Indikator Kinerja Akuntan Pendidik Dimasa Covid 19

\begin{tabular}{|c|c|c|c|c|c|c|c|c|c|c|}
\hline No & $\begin{array}{l}\text { Pendidikan } \\
\text { dan } \\
\text { Pengajaran }\end{array}$ & $\%$ & Penelitian & $\%$ & $\begin{array}{l}\text { Pengabdian } \\
\text { Masyarakat }\end{array}$ & $\%$ & $\begin{array}{l}\text { Aplikasi } \\
\text { yang } \\
\text { digunakan }\end{array}$ & $\%$ & $\begin{array}{c}\text { Media } \\
\text { Sosial } \\
\text { yang } \\
\text { digunakan }\end{array}$ & $\%$ \\
\hline 1 & $\begin{array}{l}\text { Kuliah } \\
\text { daring/onlin e }\end{array}$ & 100 & $\begin{array}{l}\text { Melakukan } \\
\text { Penelitian } \\
\text { secara daring }\end{array}$ & 8,23 & $\begin{array}{l}\text { Melakukan } \\
\text { kegiatan } \\
\text { pengabdian } \\
\text { secara } \\
\text { daring }\end{array}$ & $\begin{array}{l}82, \\
11\end{array}$ & $\begin{array}{l}\text { Zoom } \\
\text { meeting }\end{array}$ & 21 & Whatapps & 62 \\
\hline 2 & $\begin{array}{l}\text { Penugasan } \\
\text { mahasiswa }\end{array}$ & 100 & $\begin{array}{l}\text { Rapat dan } \\
\text { diskusi secara } \\
\text { daring }\end{array}$ & 67,88 & $\begin{array}{l}\text { Melaksanak } \\
\text { an } \\
\text { seminar/for } \\
\text { um diskusi } \\
\text { ilmiah } \\
\text { secara daring }\end{array}$ & $\begin{array}{l}64, \\
33\end{array}$ & $\begin{array}{l}\text { Google } \\
\text { Meet }\end{array}$ & 15 & Facebook & 11 \\
\hline 3 & $\begin{array}{l}\text { Ujian Tengah } \\
\text { Semester }\end{array}$ & 100 & $\begin{array}{l}\text { Mengikuti } \\
\text { konferensi } \\
\text { hasil } \\
\text { penelitian } \\
\text { secara } \\
\text { daring }\end{array}$ & 1,44 & $\begin{array}{l}\text { Menjadi } \\
\text { narasumber/ } \\
\text { pembicara } \\
\text { secara daring }\end{array}$ & $\begin{array}{l}4,1 \\
1\end{array}$ & $\begin{array}{l}\text { Google } \\
\text { Class } \\
\text { Room }\end{array}$ & 45 & Instagram & 8 \\
\hline 4 & $\begin{array}{l}\text { Rencana } \\
\text { Ujian Akhir } \\
\text { Semester }\end{array}$ & 100 & $\begin{array}{l}\text { Menerbitk } \\
\text { an Publikasi } \\
\text { hasil } \\
\text { penelitian }\end{array}$ & 2,39 & & & $\begin{array}{l}\text { Webex } \\
\text { cisco }\end{array}$ & 3 & Twitter & 7 \\
\hline 5 & $\begin{array}{l}\text { Bimbingan } \\
\text { Skripsi, } \\
\text { tesis dan } \\
\text { Disertasi }\end{array}$ & 100 & & & & & $\begin{array}{l}\text { Aplikasi } \\
\text { kampus }\end{array}$ & 10 & $\begin{array}{l}\text { Komunit } \\
\text { as kampus }\end{array}$ & 9 \\
\hline & & & & & & & lainnya & 11 & lainnya & 6 \\
\hline
\end{tabular}

Sumber : Data penelitian (2020)

Berdasarkan data indikator capaian kinerja secara daring dapat dijelaskan bahwa untuk kegiatan pendidikan dan pengajaran berjalan sebesar 100 persen artinya semua akuntan pendidik di Sumatera Utara telah melaksanakan sistem pengajaran proses belajar mengajar secara daring. Akan tetapi untuk kegiatan penelitian masih mengalami kendala karena jenis penelitian yang dapat dilakukan secara daring adalah data sekunder sedangkan untuk data primer masih terjadinya kesulitan pada distribusi dan pengumpulan data lapangan. Kemudian untuk kegiatan pengabdian masyarakat para akuntan pendidik masih terfokus pada berbagai kegiatan khususnya pemberian bantuan kepada masyarakat untuk meringankan beban dampak covid-19 yaitu dengan pemberian sembako, penyemprotan disinfektan, dan melakukan himbauan himbauan penanggulangan covid-19 baik secara individu maupun institusi dimasing-masing perguruan tinggi.

Selanjutnya hasil pengujian statistik deskriptif dapat dilihat pada tabel 5 berikut :

Tabel 5. Statikstik Dekriptif, Validitas, Reliabilitas Variabel Penelitian

\begin{tabular}{|c|c|c|c|c|c|c|c|c|}
\hline \multirow[t]{2}{*}{ Variabel } & \multicolumn{2}{|c|}{$\begin{array}{l}\mathrm{S} \\
\mathrm{k} \\
\mathrm{o} \\
\mathrm{r} \\
\end{array}$} & \multirow[t]{2}{*}{ Mean } & \multirow[t]{2}{*}{ Median } & \multirow[t]{2}{*}{ Modus } & \multirow[t]{2}{*}{$\begin{array}{l}\text { Standar } \\
\text { Deviasi }\end{array}$} & \multirow[t]{2}{*}{ Validitas } & \multirow[t]{2}{*}{ Reliabilitas } \\
\hline & $\begin{array}{l}\text { Minim } \\
\text { al }\end{array}$ & $\begin{array}{c}\text { Maksi } \\
\text { mal }\end{array}$ & & & & & & \\
\hline $\begin{array}{l}\text { Pemahaman } \\
\text { Bencana }\end{array}$ & 1 & 9 & 8,72 & 7,11 & 8,00 & 1,21 & 0,0003 & 0,856 \\
\hline
\end{tabular}


Model Respon Emergensi Bencana Dan Pengaruhnya

Terhadap Kinerja Akuntan Pendidik Dalam Pandemi

Covid-19 Di Provinsi Sumatera Utara

\begin{tabular}{|l|c|c|c|c|c|c|c|c|}
\hline $\begin{array}{l}\text { Pengalaman } \\
\text { Bencana }\end{array}$ & 1 & 9 & 4,33 & 4,63 & 4,00 & 1,10 & 0,0002 & 0,714 \\
\hline $\begin{array}{l}\text { Pengetahuan } \\
\text { Regulasi }\end{array}$ & 1 & 9 & 4,77 & 4,22 & 4,00 & 1,06 & 0,0001 & 0,738 \\
\hline $\begin{array}{l}\text { Respon } \\
\text { Emergensi }\end{array}$ & 1 & 9 & 6,55 & 7,42 & 7,00 & 1,23 & 0,0001 & 0,861 \\
\hline $\begin{array}{l}\text { Kinerja } \\
\text { Akuntan } \\
\text { Publik }\end{array}$ & 1 & 9 & 8,16 & 7,99 & 8,00 & 1,44 & 0,0002 & 0,832 \\
\hline
\end{tabular}

Sumber : Data penelitian (2020)

Berdasarkan data deskriptif variabel penelitian diketahui bahwa variabel bencana dan pengetahuan regulasi nilai rata-rata masih realtif rendah yaitu pengalaman bencana sebesar 4,33 dan pengetahuan regulasi sebesar 4,77 artinya kedua variabel ini masibh belum di pahami secara baik oleh responden. Dengan demikian untuk akuntan pendidik di Sumatera Utara harus lebih ditingkatkan tentang pengetahuan regulasi kebencanaan. Hasil pengujian validitas dan reliabilitas juga menujukkan nilai yang baik artinya butir-butir pertanyaan cukup valid untuk menjawab masalah dan dapat diandalkan berdasarkan kriteria Nunally nilai skor $>0,50$.

Data terdistribusi secara normal berdasarkan uji One Sample Kolmogorov Smirnov yaitu menunjukkan nilai 0,003 signifikan dibawah 0,05. Pengujian asumsi klasik dilakukan pada multikolinierity untuk memastikan tidak terdapat hubungan antar variabel independen berdasarkan nilai toleransi dan nilai variance inflation factor (VIF), yaitu sebesar 0,47 artinya tidak terjadi multikolinierity. Untuk uji autokorelasi dan heterokedastisitas pengambilan keputusan uji statistik dilakukan dengan run test (Ghozali, 2018:116) dan menujukkan nilai 0,0002 artinya tidak terjadi heterokedastisitas pada model 1 dan model 2 persamaan regresi penelitian ini. Hasil analisis data over all best fit model menunjukkan bahwa Nilai $R$ Square estimasi model 1 adalah sebesar 62,37 \%, model kedua yaitu $64,18 \%$ dan model ketiga sebesar $52,11 \%$ pada multiple regression yang didasarkan pada teknik estimasi likelihood dari koefisien cox and snell $R$ square. Kesimpualnnya adalah model ini memiliki kekuatan estimasi yang sangat baik karena nilai diatas $50 \%$, artinya model dapat digunakan dan dikembangkan Adapun hasil pengujian hipotesis dirinci pada tabel 6 berikut:

Tabel 6: Hasil Pengujian Hipotesis

\begin{tabular}{|c|c|c|c|c|c|c|}
\hline \multirow{2}{*}{ Hipotesis } & \multicolumn{2}{|c|}{ Hubungan antar variabel } & \multirow{2}{*}{ Coefficients } & \multirow{2}{*}{ T Statistics } & \multirow{2}{*}{$P$ Values } & \multirow{2}{*}{$\begin{array}{c}\text { Hasil } \\
\text { Penelitian }\end{array}$} \\
\hline & Dari & $\mathrm{Ke}$ & & & & \\
\hline $\mathrm{H} 1$ & $\begin{array}{c}\text { Pemahaman } \\
\text { bencana }\end{array}$ & $\begin{array}{c}\text { Respon } \\
\text { emergensi }\end{array}$ & 0,278 & 2,837 & 0,004 & $\begin{array}{l}\text { Hipotesis } \\
\text { Diterima }\end{array}$ \\
\hline $\mathrm{H}_{2}$ & $\begin{array}{c}\text { Pengalaman } \\
\text { bencana }\end{array}$ & $\begin{array}{c}\text { Respon } \\
\text { emergensi }\end{array}$ & 0,239 & 1,101 & 0,272 & $\begin{array}{c}\text { Hipotesis } \\
\text { Ditolak }\end{array}$ \\
\hline $\mathrm{H} 3$ & $\begin{array}{l}\text { Pengetahuan } \\
\text { regulasi }\end{array}$ & $\begin{array}{c}\text { Respon } \\
\text { emergensi }\end{array}$ & 0,151 & 1,075 & 0,283 & $\begin{array}{c}\text { Hipotesis } \\
\text { Ditolak }\end{array}$ \\
\hline $\mathrm{H}_{4}$ & $\begin{array}{c}\text { Pemahaman } \\
\text { bencana }\end{array}$ & $\begin{array}{c}\text { Kinerja } \\
\text { Akuntan } \\
\text { Pendidik }\end{array}$ & 0,760 & 8,870 & 0,000 & $\begin{array}{l}\text { Hipotesis } \\
\text { Diterima }\end{array}$ \\
\hline $\mathrm{H} 5$ & $\begin{array}{c}\text { Pengalaman } \\
\text { bencana }\end{array}$ & $\begin{array}{c}\text { Kinerja } \\
\text { Akuntan } \\
\text { Pendidik }\end{array}$ & 0,226 & 1,490 & 0,003 & $\begin{array}{l}\text { Hipotesis } \\
\text { Diterima }\end{array}$ \\
\hline H6 & $\begin{array}{l}\text { Pengetahuan } \\
\text { regulasi }\end{array}$ & $\begin{array}{c}\text { Kinerja } \\
\text { Akuntan } \\
\text { Pendidik }\end{array}$ & 0,564 & 4,353 & 0,000 & $\begin{array}{l}\text { Hipotesis } \\
\text { Diterima }\end{array}$ \\
\hline & $\begin{array}{l}\text { Respon } \\
\text { emergensi }\end{array}$ & $\begin{array}{c}\text { Kinerja } \\
\text { Akuntan } \\
\text { Pendidik }\end{array}$ & 0,830 & 4,505 & 0,000 & $\begin{array}{l}\text { Hipotesis } \\
\text { Diterima }\end{array}$ \\
\hline
\end{tabular}




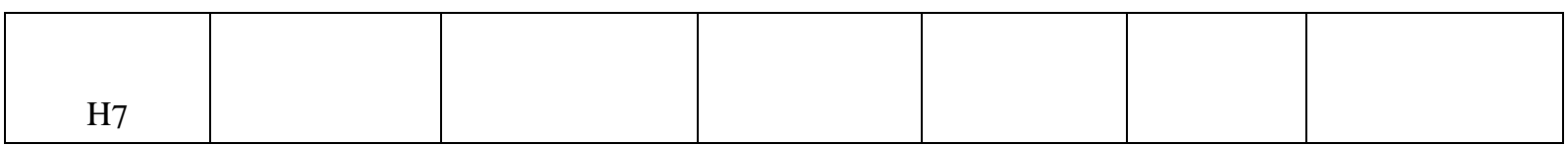

Sumber : Hasil analisis penelitian (2020)

Berdasarkan tabulasi hasil pengujian hipotesis sebagaimana yang diuraikan pada tabel 6 (enam) diatas maka dapat dijelaskan bahwa dari sebanyak 7 (tujuh) hipotesis yang diajukan dalam penelitian ini, terdapat 5 (lima) hipotesis yang dapat diterima dan berpengaruh secara signifikan, sedangkan 2 (dua) hipotesis lainnya tersebut yang tidak berpengaruh yaitu pada variabel pengalaman bencana dan pengetahuan regulasi bencana yang dihubungkan kepada model respon emergensi.Interpretasi hasil pengujian hipotesis dapat dijelaskan bahwa variabel pengalaman bencana tidak berpengaruh dengan nilai signifikansi 0,272 hal ini tidak sejalan dengan penelitian Ayub (2017) yang membuktikan pengalaman bencana menjadi faktor penentu kesiapsiagaan bencana. Menurut Ayub (2017) jika masyarakat belum pernah mengalami suatu bencana maka sangat minim respon dan kesiapan menghadapi suatu bencana. Fakta ini dapat menjelaskan bahwa tidak banyak akuntan pendidik di Sumatera Utara yang pernah mengalami bencana dalam skala besar sehingga respon terhadap bencana menjadi tidak signifikan, namun demikian pada model persamaan ke 2 (dua) mengenai pengalaman bencana tetap berpengaruh terhadap kinerja akuntan pendidik. Demikian juga pada hipotesis 5 (lima) sehingga dapat dijelaskan bahwa walaupun dalam keadaan terjadinya bencana akuntan pendidik masih tetap dapat berkinerja secara optimal. Hal yang sama juga dikemukakan oleh Letshwene (2014) yang menjelaskan bahwa tantangan untuk menghasilkan kinerja bagi tenaga pengajar akuntansi memang selalu berkembang dan dinamis. Perubahan untuk tantangan kinerja tersebut dapat dijelaskan dengan teori kontinjensi.

Kemudian hipotesis ke 3 juga tidak signifikan artinya akuntan pendidik di Sumatera Utara masih kurang memahami permasalahan peraturan dan perundangan terkait kebencanaan baik tingkat lokal, nasional maupun internasional hal ini dapat dipahami secara professional akuntan pendidik harus fokus pada bidang profesionalismenya seperti yang dikemukakan oleh Agustia (2019). Hal ini juga dapat dijelaskan dengan pendapat Trisnaningsih, dkk (2012) yang menyatakan bahwa penelitian yang menghubungkan komitmen organisai dan komitmen individu terhadap kinerja dosen akuntansi demikian penting menurut persepsi dosen akuntansi. Artinya akuntan pendidik sangat fokus pada bidang yang ditekuninya. Adapun relevansi temuan tersebut dengan penelitian ini adalah dapat menjelaskan bahwa komitmen individu untuk menghasilkan kinerja dimiliki oleh profesi akuntan pendidik. Jika dikaitkan secara grand teori baik kontijensi maupun stakeholder teori, model respon cepat yang diuji telah membuktikan bahwa suatu kondisi akan cepat menyesuaikan dengan tujuan yang ingin dicapai dan sangat dinamis atau bersifat kontinjensi, dan sikap tersebut ternyata dimiliki oleh akuntan pendidik.Sedangkan secara konsep stakeholder yang dinyatakan oleh Friedman, (2007) bahwa keterkaitan satu stakeholder dengan entitas menjadi penentu keberlangsungan entitas tersebut, artinya akuntan pendidik respon dalam menghadapi bencana walaupun ada kalanya tidak memahami betul hal tersebut karena diluar fokus dan kompetensi profesionalismenya.

Pada penelitian ini stakeholder akuntan pendidik dapat dimaknai sebagai mahasiswa, perguruan tinggi, pemerintah dan masyarakat, penyedia sarana teknologi informasi dan komunikasi. Ketika covid-19 terjadi akuntan pendidik sesuai regulasi permeintah harus bekerja dari rumah untuk mengajar secara daring, membimbing, menguji mahasiswa yang memiliki keterkaitan satu dengan lainnya, sehingga pencapaian kinerja akuntan pendidik harus terwujud dalam kondisi apapun dengan dukungan stakeholder. Disinilah peran organisasi akuntan pendidik yaitu IAI KAPd untuk terus memfasilitasi anggotanya dalam pencapaian kinerja. Secara keseluruhan penelitian ini masih mendukung teori kontinjensi dan teori stakeholder bagi akuntan pendidik dalam melihat sebuah kondisi dan meningkatkan sinergitas stakeholder untuk mencapai kinerja yang lebih baik. Model ini merupakan kerangka awal penggabungan kinerja dan respon emergensi terhadap suatu kejadian bencana. Penggabungan dua faktor ini diharapkan dapat menjadi referensi pengembangan kerangka teoritis dan konseptual bagi peningkatan pendidikan akuntansi dan peningkatan kinerja akuntan pendidik. Dengan dilakukannya penelitian ini maka variabel yang lebih luas sebagaimana dikemukakan oleh teori stakeholder sangat memungkinkan untuk dikembangkan untukmemperkuat model penapaian kinerja akuntan publik dalam keadaan bencana ataupun kondisi darurat tertentu. 


\section{Model Respon Emergensi Bencana Dan Pengaruhnya Terhadap Kinerja Akuntan Pendidik Dalam Pandemi Covid-19 Di Provinsi Sumatera Utara}

Sejalan dengan penelitian ini Kitindi (2009) menyatakan bahwa kinerja akuntan pendidik memang harus ditingkatkan secara berkelanjutan. Walaupun keseluruhan pendapat para peneliti dan pakar tentang kinerja akuntan pendidik dalam asumsi normal, maka dengan adanya situasi kondisi covid-19 membuktikan bahwa akuntan pendidik tetap dapat berkinerja dalam situasi dan kondisi apapun. Dosen merupakan individu yang dianggap mahasiswa paling berperan terhadap prestasi akademik dirinya. Kinerja dosen yaitu ukuran sejauh mana proses dan hasil dari pekerjaan dosen. Ariyani (2009) menerangkan yang dimaksud dengan kinerja dosen yaitu hasil dari prestasi kerja yang telah dicapai seseorang sesuai dengan fungsi tugasnya sebagai pembimbing mahasiswa. Ketika seorang dosen menjelaskan tentang materi pelajaran dengan tindakan (action) yang sangat baik, namun mahasiswa belum memahami materi pelajaran (outcome) tersebut, maka dapat dikatakan kinerja dosen tersebut tidak baik, karena dosen belum mampu menyampaikan materi pembelajaran yang dapat dipahami oleh mahasiswa (Sonnentag, 2001). Dengan demikian dapat dikatakan semakin baik pemahaman Dosen Akutnansi/Akuntan Pendidik terhadapa persoalan bencana maka Kinerja akuntan pendidik dapat dipertahankan sebagaimana kondisi normal. Hal ini sejalan dengan apa yang dikatakan oleh mathew (2004) bahwa pengedalian stress, motivasi dalam keadaan tertentu semuanya dapat menjadi perbandingan bagi para indoividu untuk mempertahankan kinerjanya masing-masing dalam situasi dan kondisi apapun, khusunya dalam persoalan bencana.

\section{Kesimpulan}

Berdasarkan hasil analisis data tersebut diatas maka dapat disimpulkan bahwa respon emergensi terhadap bencana cukup baik dan berpengaruh terhadap kinerja akuntan pendidik, namun masih harus ditingkatkan pada aspek pengetahuan tentang regulasi kebencanaan agar respon emergensi/kesiapsiagaan dikalangan akuntan pendidik menjadi lebih baik dan dapat ditingkatkan dimasa yang akan datang.

Penelitian ini berimplikasi pada pentingnya tersedia standar operasional dan prosedur bagi profesi akuntan pendidik dalam menyikapi terjadinya suatu keadaan bencana yang bisa saja terjadi diluar prediksi organisasi profesi. Untuk itu IAI KAPD dan umumnya organisasi IAI dapat merumuskan aturan organisasi terkait pentingnya respon emergensi bagi kalangan akuntan pendidik dalam menghadapi suatu kejadian bencana di kemudian hari.

Keterbatasan penelitian ini adalah pada metode pengambilan sampel dengan teknik kemudahan sehingga dikhawatirkan tidak menjadi re-presentatif bagi akuntan pendidik/akademisi dibidang akuntansi untuk itu penelitian mendatang direkomendasikan untuk memilih teknik pengambilan sampel yang lebih tepat dan sebaiknya dapat dilakukan pada bidang profesi akuntan lainnya seperti akuntan manajemen dan akuntan publik yang secara praktiknya dilapangan banyak berinteraksi dengan dunia bisnis dan lebih berisiko. Keterbatasan kedua adalah minimnya referensi penelitian tentang kebencanaan dikalangan profesi akuntan sehingga penelitian lanjutan harus mengembangkan model penelitian dengan menambah variabel pendukung penguatan model respon emergensi. Keterbatasan ketiga adalah wilayah penelitian yang hanya pada satu provinsi dikhawatirkan memiliki daya generalisasi yang lemah untuk itu penelitian lanjutan disarankan untuk memilih wilayah cakupan area penelitian yang lebih luas misalnya skala nasional, regional kawasan ASEAN bahkan ditingkat mancanegara.

\section{Referensi}

Anderson and King. 2005. Mitigation of the Impact of Tropical Cyclones in Northern Australia through Community Capacity Enhancement. Volume 10, Issue 3, pp 367-392.

Ayub, Muhammad, Makhrus,dkk, 2017, Analisis Kesiapsiagaan Bencana Pada Guru Sekolah Dasar, 1Program Studi Pendidikan Fisika, Fakultas Keguruan dan Ilmu Pendidikan, Universitas Mataram, Mataram, Indonesia, Jurnal Penelitian Pendidikan IPA, 10.29303/jppipa.v6i1.281 pp. 52-56.

Azizul Kholis. 2012. Faktor Penentu Profesionalisme Dosen Akuntansi, Proseeding, Simposium 


\section{Model Respon Emergensi Bencana Dan Pengaruhnya \\ Terhadap Kinerja Akuntan Pendidik Dalam Pandemi Covid-19 Di Provinsi Sumatera Utara}

Nasional penelitian dan Kebijakan Pendidikan, Departemen Pendidikan nasional RI, Jakarta

Badan Nasional Penanggulangan Bencana. 2012. Peraturan Kepala Banda Nasional Penanggulangan Bencana Nomor 1 Tahun 2012 tentang Pedoman Umum Desa/Kelurahan Tangguh Bencana. BNPB

Catherine, L. M. 2020. Real and financial lenses to assess the economic consequences of COVID19 A CEPR Press VoxEU.org eBook, CEPR Press. ISBN: 978-1-912179-28-2, Web:www.cepr.org

Dian Agustia. 2019. Kesiapan Profesi Akuntan pendidik Indonesia dalam era Distrupsi dan memasuki Revolusi industry 4.0, Simpisum Ilmiah Akuntansi, IAI KPd Wilayah Sumut, Universitas Methodist Indonesia.

Dirjen Dikti Kemendibud RI, Surat edaran nomor :302/E.E2/KR/2020 tanggal 31 Maret 2020

Ella dan Usman. 2008. Mencerdasi Bencana, Penerbit Grasindo, Jakarta

Enny Susilowati Mardjono dan Baningatus Solikhan, 2014. Profesionalisme Akuntan Pendidik : Perspektif Atau Triger Kualitas Lulusan Akuntansi Di Era Masyarakat Ekonomi Asean, Jurnal Akuntansi \& Auditing Volume 11/No. 1/ November 2014 : 103 - 119 1. Email : ennyyoi@yahoo.co.id dan badingatusbety@gmail.com

Friedman, 2007. Stakeholder Theory: Approach for bussisnes and Social performance, Springer Publisher, Newyork,USA

Gunawan. 2008. Kondisi Sosial Masyarakat dalam Manajemen Bencana. Yogyakarta.

Hall. 2015. Conceptual framework of Stake holder Theory : based on Friedman Model, Willey Inc, Publisher, USA

Imam Ghozali. 2016. Aplikasi Analisis Multivariete Dengan Program SPSS 23 (Edisi 8). Cetakan ke VIII. Semarang : Badan Penerbit Universitas Diponegoro.

Imam Ghozali. 2018. Analisis statistic menggunakan aplikasi Wrap PLS (Edisi 8). Cetakan ke I, Semarang : Badan Penerbit Universitas Diponegoro.

International Monetary Fund, 2019. Global Financial Stability Report, Washington DC.

Irman Oemar, 2020. Perlukah Sumut memberlakukan PSBB, Artikel opini, harian Waspada, terbitan 27 Maret 2020, akses online http://www. waspadaonline.co.id

Jocobine, L. 2014. Improving grade 10 accounting teachers' competencies in the ekurhuleni district of the gauteng provincebym, Theses, University of South Africa.

Kemendikbud RI, Surat Edaran Nomor 4 Tahun 2020 tentang Pelaksanaan Pendidikan Dalam Masa Darurat Corona virus Disease (Covid-19) akses pada www.kemendikbud,go.id

Kitindi, E. G. and Mgaya, 2009. K. V. 'Essential skills needed by accounting graduates in a developing country: the views of practicing accountants and accounting educators in Botswana',in Foong, S.Y. and Noghondari, A.T. (eds). International Journal: Accounting, Auditing and Performance Evaluation, 5(3): 329-349.

Lembaga Ilmu Pengetahuan Indonesia SCO/ISDR. 2006. Sebuah Kajian dan Studi tentang Kesiapsiagaan Masyarakat dalam Mengantisipasi Bencana Gempa Bumi dan Tsunami. Deputi Ilmu Pengetahuan Kebumian Lembaga Ilmu Pengetahuan Indonesia. Jakarta.

Maheran, Z., Wan Noor Asmuni, F. \& Hasan, S.J. 2012. 'Accounting as a choice of academic program', Journal of Businesses Administration Research, 1(1): 43-52. [online].Available at: http://dx.dx.doi.org/10.5430/jbar.v/n/p43>[Accessed15 January 2013]

Marvin 1. Birnbaum md, Elaine Daily, 2012. "Health Disaster Management", University of Wisconsin school of Medicine and Public Health, Madison Past President, the World Association for Disaster and Emergency Medicine

Mas Nur Mukmin dan Hesti Wulansari, 2017. Akuntabilitas Kinerja Akuntan Pendidik Berdasarkan Kompetensi Akuntan Dan Etika Profesional (Studi Empiris Pada Perguruan Tinggi Swasta Di Bogor) Jurnal Akunida ISSN 2442-3033 Volume 3 Nomor 2, Desember 2017 DOI: 10.30997/jakd.v3i2.979,

Paisey, C.,Paisey, N. \&Tarbert, H. 2007. 'Continuing professional development activities of UK accountants in public practice', in Wessels, B.S. (ed). Accounting Education: An International Journal,16(4): 379- 403.

Peraturan Pemerintah No 21 tahun 2020 tentang Pembatasan Sosial Berskala Besar (PSBB), Menteri Sekretaris Negara RI, Jakarta akses pada www.setneg,go.id 


\section{Model Respon Emergensi Bencana Dan Pengaruhnya \\ Terhadap Kinerja Akuntan Pendidik Dalam Pandemi Covid-19 Di Provinsi Sumatera Utara}

Permenkes No. 9 Tahun 2020 tentang mekanisme Pembatasan Sosial Berskala Besar (PSBB), Kementerian Kesehatan RI, Jakarta, akses pada www.kemenkes,go.id

Posner, K. \& Dransch, D, 2010. Volunteered geographic information for disaster management with application to rapid flood damage estimation. Geomatica, 64(1), pp: 89-98.

Priyanto, A. 2006. Promosi Kesehatan Pada Situasi Emergensi Edisi 2. Jakarta.

PSB-UGM.2009. Reorientasi Pendidikan Kebencanaan dalam Rangka Pengurangan Risiko Bencana.Seminar Nasional. Reorientasi Pendidikan Kebencanaan Yogyakarta

Richard Baldwin and Eiichi Tomiura, 2020. Thinking ahead about the trade impact of COVID-19 A CEPR Press VoxEU.org eBook, CEPR Press. ISBN: 978-1-912179-28-2, Web: www.cepr.org

Sawitri, A. P. dan Fauziyah, 2017. Peran Akuntan Pendidik dalam Meningkatkan Profesionalisme Calon Akuntan. Jurnal Studi Manajmen dan Bisnis, Prodi MM Universitas Trunojoyo, Madura

Sekaran Uma,2005. Research Methodology for Business, A Multivariate Approach, Prentice hall Publisher, London

Simon, L.W. 2020. Pandemi Impact of Economic, A CEPR Press VoxEU.org eBook, CEPR Press. ISBN: 978-1-912179-28-2, Web: www.cepr.org

Sri Trisnaningsih, Suparwati, Failasuf Herman Hendra, 2012 The Factors That Influence To Lecturers Performance With Motivation As An Intervening Variable, The Fourth UB international Consortium of Accounting, UB, Malang

Sutton, J., and Tierney, K. 2006.Dissaster Preparedness: Concepts, Guidance and Research. University of Colorado. Colorado

Swiss Re, 2011. Natural Catastrophe and Man-Made Disaster in 2011: Historic Losses Surface From Record Earthquake And Floods. Report prepared for Swiss Reinsurance Company Ltd.(Publication No. sigma No2/2012), Economic Research and Consulting, Switzerland.

Twigg, J, 2007. Characteristics of a Disaster-Resilient Community: A Guidance Note. Disaster Risk Reduction Interagency Coordination Group, DFID. 95.Twigg, J. (2015). Disaster risk reduction. Good Practice Review 9. London: Humanitarian Practice Network

World Health Organization, 2003. "Severe acute respiratory syndrome (SARS): Status of the outbreak and lessons for the immediate future", Geneva

World Health Organization, 2009. "Pandemi influenza preparedness and response: a WHO guidance document", Geneva.

World Health Organization, 2013. A Systematic Review of Public Health Emergency Operations Centres (EOC). World Health Organization.WHO/HSE/GCR/2014.1. Retrieved from: http://apps.who.int/iris/bitstream/10665/99043/1/WHO_HSE_GCR_2014.1_eng.pdf119.

World Health Organization, 2016. "WHO MERS-CoV Global Summary and risk assessment", Geneva.

Yates, T., Vujcic, J., Joseph, M.L., \& Lantagne, D. 2015. Protocol: Short-term Hygiene Interventions in Emergency Response Situations: A Systematic Review and Impact Analysis. International Initiative for Impact Evaluation(3ie).

Zhong, S., Clark, M., Hou, X.Y., Zang, Y., \& FitzGerald G. (2014). Progress and challenges of disaster health management in China: a scoping review.Global Health Action, 7, pp: 1-9.121.

Zwi, A., Spurway, K., Ranmuthugala, G., Marincowitz, R., Thompson, L., \& Hobday, K. (2013). Do Community Based Disaster Risk Management (CBDRM) Initiatives Reduce The Social and Economic Cost of Disasters? Protocol. EPPI-Centre, Social Science Research Unit, Institute of Education, University of London. 